\title{
Cytoarchitecture of the medial nucleus of trapezoid body of three neotropical species of bats (Noctilio leporinus, Phyllostomus hastatus, and Carollia perspicillata) with different foraging behavior
}

\author{
I. Gibbons ${ }^{a}$ (D), V. Sundaram ${ }^{a *}$ (D), A. Adogwa ${ }^{a}$ (D) and A. Odekunle ${ }^{b}$ (D) \\ ${ }^{a}$ Department of Basic Veterinary Sciences, School of Veterinary Medicine, Faculty of Medical Sciences, The University of \\ the West Indies, St. Augustine, Trinidad and Tobago \\ ${ }^{\mathrm{b}}$ Anatomy Unit, Department of Preclinical Sciences, School of Medicine, Faculty of Medical Sciences, The University of \\ the West Indies, St. Augustine, Trinidad and Tobago \\ *e-mail: drvenkat1971@gmail.com
}

Received: October 24, 2019 - Accepted: May 22, 2020 - Distributed: November 30, 2021

(With 3 figures)

\begin{abstract}
The present study was taken to test the hypothesis that the medial nucleus of the trapezoid body (MNTB) of echolocating neotropical bats with different foraging behavior will exhibit morphological variations in relative size, degree of complexity and spatial distribution. The brains were collected from six male adult bats of each species: Noctilio leporinus (fish-eating), Phyllostomus hastatus (carnivorous/ omnivorous) and Carollia perspicillata (fruit-eating) and were double-embedded and transverse serial sections were cut and stained with cresyl fast violet. The results showed that the MNTB is well developed in all the bats in general and the mean length of the MNTB was $1160 \pm 124 \mu \mathrm{m}$ in $N$. leporinus, $400 \pm 59 \mu \mathrm{m}$ in $P$. hastatus and $320 \pm 25 \mu \mathrm{m}$ in C. perspicillata. The body and brain weight do not reflect proportionately on the size of the MNTB in the present study. The hearing frequency spectrum did not covary with the size of the MNTB among the bats studied. The MNTB is clearly demarcated from the ventral nucleus of the trapezoid body (VNTB) only in P. hastatus. The MNTB comprised mainly three types of cells in all three bats: dense-staining multipolar cells $(12.5 \mu \mathrm{m}$ and $25.0 \mu \mathrm{m}$ diameter); light-staining multipolar cells measuring $(12.5 \mu \mathrm{m}$ and $25.0 \mu \mathrm{m}$ diameter) and light-staining round cells (5.0 $\mu \mathrm{m}$ diameter). The large sized MNTB was observed in $N$. leporinus, which suggests that it relies heavily on echolocation whereas P. hastatus and C. perspicillata use echolocation as well but also rely on hearing, smell and vision.
\end{abstract}

Keywords: medial nucleus of trapezoid nucleus, cytoarchitecture, Noctilio leporinus, Phyllostomus hastatus, Carollia perspicillata.

\section{Citoarquitetura do núcleo medial do corpo trapezoidal de três espécies neotropicais de morcegos (Noctilio leporinus, Phyllostomus hastatus e Carollia perspicillata) com diferentes comportamentos de forrageamento}

\section{Resumo}

O presente estudo foi realizado para testar a hipótese de que o núcleo medial do corpo trapezoide (MNTB) de morcegos neotropicais ecolocativos com comportamento forrageiro diferente apresenta variações morfológicas no tamanho relativo, grau de complexidade e distribuição espacial. Os cérebros foram coletados de seis morcegos machos adultos de cada espécie, Noctilio leporinus (comedor de peixe), Phyllostomus hastatus (carnívoro/onívoro) e Carollia perspicillata (comedor de frutas), e foram seccionados em série e seções seriais transversais duplas e coradas com cresil violeta. Os resultados mostraram que o MNTB é bem desenvolvido em todos os morcegos em geral e que o comprimento médio do MNTB foi de $1.160 \pm 124 \mu \mathrm{m}$ em N. leporinus, $400 \pm 59 \mu \mathrm{m}$ em P. hastatus e $320 \pm 25 \mu \mathrm{m}$ em C. perspicillata. O peso corporal e cerebral não reflete proporcionalmente o tamanho do MNTB no presente estudo. $\mathrm{O}$ espectro da frequência auditiva não covaria com o tamanho do MNTB entre os morcegos estudados. O MNTB é claramente demarcado do núcleo ventral do corpo trapezoidal (VNTB) apenas em P. hastatus. O MNTB compreendia principalmente três tipos de células nos três morcegos: células multipolares de coloração densa $(12,5 \mu \mathrm{m}$ e $25,0 \mu \mathrm{m}$ de diâmetro), células multipolares de coloração clara (12,5 $\mu \mathrm{m}$ e 25,0 $\mu \mathrm{m}$ de diâmetro) e células redondas manchadas de luz (5,0 $\mu \mathrm{m}$ de diâmetro). O MNTB de grande porte foi observado em N. leporinus, o que sugere que ele depende muito da ecolocalização, enquanto P. hastatus e C. perspicillata também usam a ecolocalização, mas dependem da audição, olfato e visão.

Palavras-chave: núcleo medial do núcleo trapezoidal, citoarquitetura, Noctilio leporinus, Phyllostomus hastatus, Carollia perspicillata. 


\section{Introduction}

The medial nucleus of the trapezoid body (MNTB) is a major auditory nucleus in the brainstem located in the hind brain next to superior olive. It consists of several type of neurons and the calyces of Held, the large synaptic endings of certain auditory neurons of the anterior ventral cochlear nucleus (AVCN). It involved in the sound source localization pathway, as well as in a number of other auditory circuits (Grothe et al., 2010; Ashida and Carr, 2011; Borst and Soria van Hoeve, 2012). The principal neurons of the MNTB receive their main excitatory input from the globular bushy cells (GBCs) of the contralateral AVCN. The large diameter axons of GBCs pass in the acoustic stria and decussate at the midline within the trapezoid body (Smith et al., 1991) and terminate on principal neurons of the MNTB via a type of giant calyceal axo-somatic terminal, calyx of Held (Morest, 1968; Held, 1893) The MNTB is a major source of glycinergic inhibition to the ipsilateral medial and lateral superior olivary nuclei (MSO, LSO, respectively), the ventral and dorsal nuclei of the lateral lemniscus (VNLL, DNLL, respectively), and other targets (Harrison and Warr, 1962; Elverland, 1978; Spangler et al., 1985). The inhibition is projected chiefly to the ipsilateral lateral superior olive (LSO), which also receives excitatory input from spherical bushy cells (SBCs) of the ipsilateral cochlear nucleus. Many LSO cells, then, are excited by stimulation of the ipsilateral ear and inhibited by stimulation of the contralateral ear. As a consequence, they become the initial point at which sensitivity to interaural level disparities is processed (Smith et al., 1998). Three types of neurons viz., stellate, elongate and principal cells were identified in the MNTB of cats and rats (Morest, 1968) with a majority (82\%) of principal cells in rats (Casey and Feldman, 1985).

The auditory nuclei in general were well developed in animals with an excellent sense of hearing and echolocating capacity (Prado Reis and Abrantes Erhart, 1979). Many bats use echolocation for orientation in space and for detecting and capturing prey in total darkness (Neuweiler and Covey, 2000; Fenzl and Schuller, 2005). Echolocating bats have evolved widely diverse foraging behaviors, echolocation sound designs, and sensory/neural adaptations for the processing of echoes. The ability to locate the source of a sound is critical in echolocation and hearing in bats as it is vital for the survival of the species. Since the different bats forage different environment, it is assumed that different foraging strategies reflect on morphology of the MNTB, an important nucleus in sound localization pathway. Though few studies were done on comparative cytoarchitecture of the various auditory nuclei of echolocating bats with different foraging strategies (Gibbons et al., 2013a, b, 2019; Adogwa et al., 2014), the MNTB was not studied.

The Noctilio leporinus Linnaeus 1758, Phyllostomus hastatus Pallas 1767 and Carollia perspicillata Linnaeus 1758 are the three neotropical species of bats used in the present study based on their differing foraging behavior. The $N$. leporinus bats are carnivorous/piscivorous, eat small fish in both fresh and salt water and forage near streams, coastal marine habitats, major river basins, or other moist places (Schnitzler et al., 1994). P. hastatus bats are omnivorous, feeding on flowers, pollen, insects and small vertebrates, and forage on open and forested regions (Koay et al., 2002). C. perspicillata bats are mainly frugivorous. However, they may feed on insects and sometimes pollen which forage on moist evergreen and dry deciduous forests (Koay et al., 2003). The present study is aimed to document the structure of the MNTB of these three species of bats and correlate the findings with their foraging behavior.

\section{Material and Methods}

A total of 18 bats, six for each bat species $N$. leporinus, $P$. hastatus and $C$. perspicillata were collected for the present study. The bats used in this study were shared in collaboration with a group involved in the study of leptospirosis surveillance in bats. All animal procedures were approved by the University of the West Indies Animal Care and Use Committee, and were conducted in accordance with National Institutes of Health standards on humane treatment of laboratory animals. Each bat was anaesthetized by using xylazine ( $2 \mathrm{mg} / \mathrm{kg}$ body weight) and ketamine $(10 \mathrm{mg} / \mathrm{kg}$ body weight $)$ intramuscularly and weighed. Then each bat was euthanized by natrium pentobarbital ( $1 \mathrm{ml}$ of $20 \%$ solution $/ \mathrm{kg}$ body weight) and the brain stem of the bats were dissected out, weighed and placed in $10 \%$ buffered formalin. The brain stem samples were manually processed and double embedded (Gibbons et al., $2013 \mathrm{a}, \mathrm{b}$ ). The tissues were then blocked and transverse serial sections at $10 \mu \mathrm{m}$ thickness were made by using the rotary microtome MT 960 . Every fourth section were stained with cresyl fast violet and analyzed with the aid of Olympus BX51 System Microscope and the digital images were taken with the help of Olympus DP71 microscope digital camera. The MNTB in all bats were identified as the group of neurons located medial and ventral to the medial superior olive (MSO) based on the approximate region on the brain stem, location relative to other major nuclei, axonal bundles and neuronal morphology in the other species including bats. Descriptive statistics on the body weight, brain weight, length, height and width, cell size of the MNTB were calculated and presented as mean \pm standard deviation.

\section{Results}

\subsection{Medial nucleus of trapezoid body of the Noctilio leporinus bat}

The mean body and brain weight of $N$. leporinus bat weighed as $48.1 \pm 3.5 \mathrm{~g}$ and $6.93 \pm 0.47 \mathrm{~g}$ respectively. The MNTB was located ventral and medial to the MSO (see Figure 1A). It extended slightly more rostral and ventral than the latter but not quite as far dorsal in the brain stem. The dorsomedial peri-olivary nucleus was located dorsal to the MNTB. The MNTB extended caudo-cranially from 

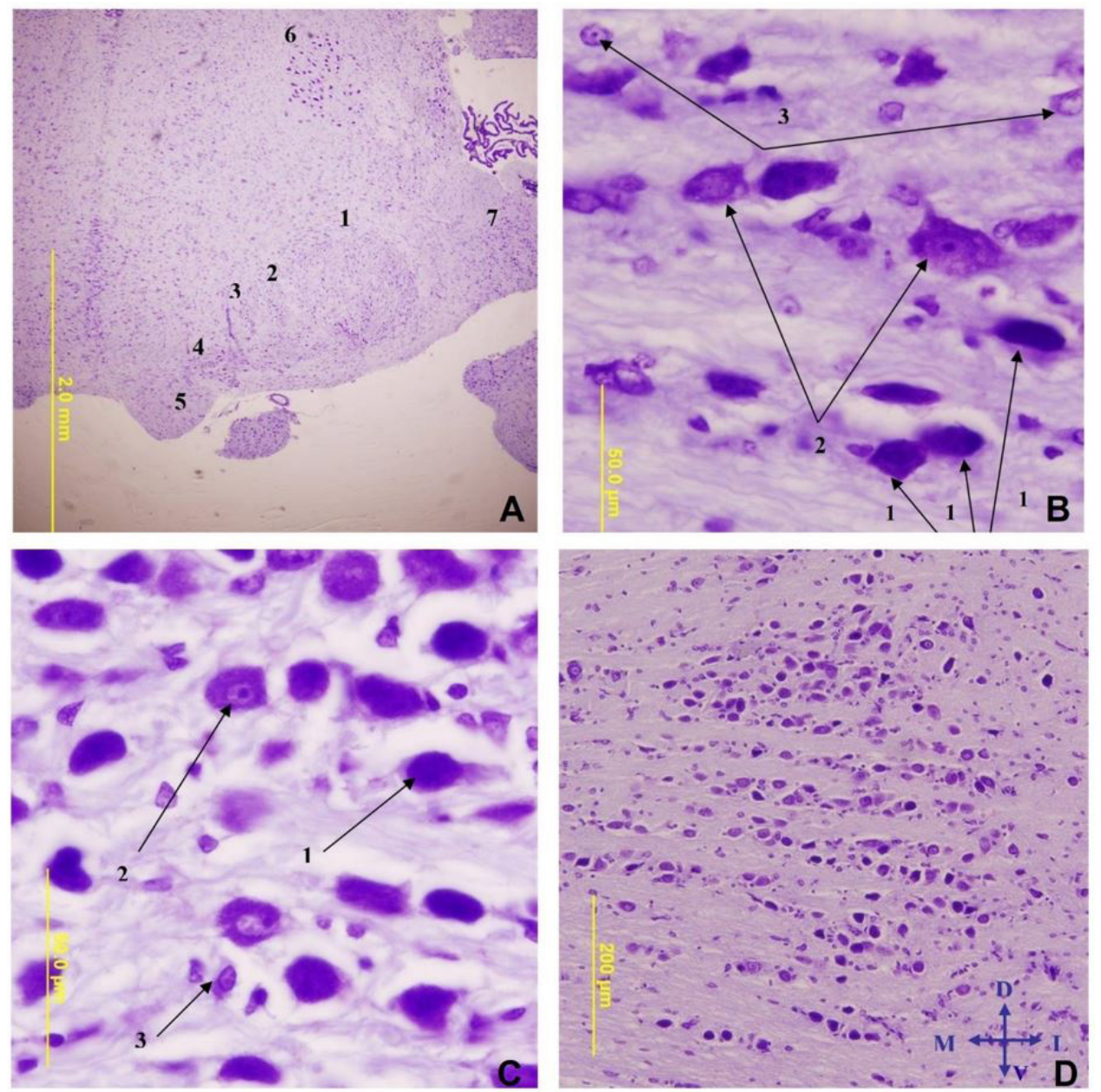

Figure 1. The MNTB of the Noctilio leporinus Bat. (A) A transverse section of the brainstem at the level of the motor nucleus of the trigeminal nerve of the N. leporinus bat. 1. Superior olivary nucleus 2. Superior paraolivary nucleus 3. Accessory superior olivary nucleus 4 . Medial nucleus of the trapezoid body 5. Pyramid 6. Motor nucleus of the trigeminal nerve 7. Superior cerebellar peduncle; (B) Cells in the medial nucleus of the trapezoid body (MNTB) at the level of the motor nucleus of the trigeminal nerve of the N. leporinus bat. 1. Dense-staining, multipolar cells (12.5 to $25.0 \mu \mathrm{m}$ diameter) 2. Light-staining, multipolar cells (12.5 to $25.0 \mu \mathrm{m}$ in diameter) 3. Light-staining, round cells (5.0 $\mu \mathrm{m}$ in diameter); (C) Relatively more dark staining cells in the middle third of the MNTB at the level of the trigeminal nerve of the Noctilio leporinus bat. 1. Dense-staining, multipolar cells (12.5 to $25.0 \mu \mathrm{m}$ diameter) 2. Light-staining, multipolar cells (12.5 to $25.0 \mu \mathrm{m}$ in diameter) 3. Light-staining, round cells (5.0 $\mu \mathrm{m}$ in diameter); (D) Extensive fibres of the trapezoid body (TB) throughout the MNTB of the N. leporinus bat, at the level of the commissure of the inferior colliculus (IC). The large, light staining cells were seen predominantly (D-Dorsal, M-Medial, L-Lateral, V-Ventral).

the level of the motor nucleus of the trigeminal nerve to the caudal end of the inferior colliculus in the brain stem with a mean length of $1160 \pm 124 \mu \mathrm{m}$. It measured $389 \pm 34 \mu \mathrm{m}$ in height and $412 \pm 55 \mu \mathrm{m}$ in width at the caudal third (at the level of the trigeminal nucleus) and increased in size at the middle third with $400 \pm 35 \mu \mathrm{m}$ in height and $500 \pm 67 \mu \mathrm{m}$ in width and diminished in size at the cranial third (ventrolateral to the medial lemniscus) to $480 \pm 29 \mu \mathrm{m}$ in height and $450 \pm 34 \mu \mathrm{m}$ in width.

Three types of cells viz., the dense staining multipolar cells, light staining multipolar cells and light staining round cells were observed in the MNTB of $N$. leporinus (see Figure 1B). These cells were scattered between the large diameter axons of the TB (see Figure 1C). The cell bodies of dense staining multipolar cells exhibited various shapes like round/ globular/ multipolar with a range of 12.5 to $25.0 \mu \mathrm{m}$ diameter (see Figure 1B, C). These cells exhibit eccentric, heterochromatic nuclei with densely scattered Nissl substance throughout the cytoplasm. These cells were predominantly scattered throughout the MNTB in the $N$. leporinus bats and considered as the principal cells. The second type of cells were the light staining multipolar cells. These cells were of same size of the dense staining multipolar cells. The cell body of the cells 
exhibited more centrally placed, euchromatic nucleus with finely distributed Nissl substance throughout the cytoplasm. These cells were found more at the level of the commissure of the inferior colliculi. The third type of cells were light staining round/oval cells with $5.0 \mu \mathrm{m}$ average diameter. They exhibited centrally placed euchromatic nuclei with eosinophilic cytoplasm. These cells were few in number and scattered throughout the MNTB between the other types of cells. The trapezoid body (TB) fibres were extensively ramified throughout the MNTB of the $N$. leporinus bat (see Figure 1D).

\subsection{Medial nucleus of trapezoid body of the Phyllostomus hastatus bat}

The mean body and brain weight of $P$. hastatus bat weighed as $73.24 \pm 7.25 \mathrm{~g}$ and $8.57 \pm 0.67 \mathrm{~g}$ respectively.
The MNTB was located as in the $N$. leporinus bats but in addition, a distinct nucleus made up of heterogenous cells was found ventrolateral to the MNTB and ventral superior olive (VSO) and forms the medial olivocochlear bundle (MOC) and identified as ventral nucleus of MNTB (VNTB) (see Figure 2A). The MNTB extended caudo-cranially from the level of middle cerebellar peduncle to the middle third of the lateral lemnisci with a mean length of $400 \pm$ $59 \mu \mathrm{m}$. It measured $500 \pm 43 \mu \mathrm{m}$ height and $460 \pm 33 \mu \mathrm{m}$ width at the caudal third and appeared to be divided into dorsal MNTB and ventral VNTB at the level of middle cerebellar peduncle and increased in size slightly at the middle third (at the level of caudal third lateral lemniscus) with the measurements of $520 \pm 54 \mu \mathrm{m}$ height and $480 \pm$ $23 \mu \mathrm{m}$ width and it became larger and denser at the rostral
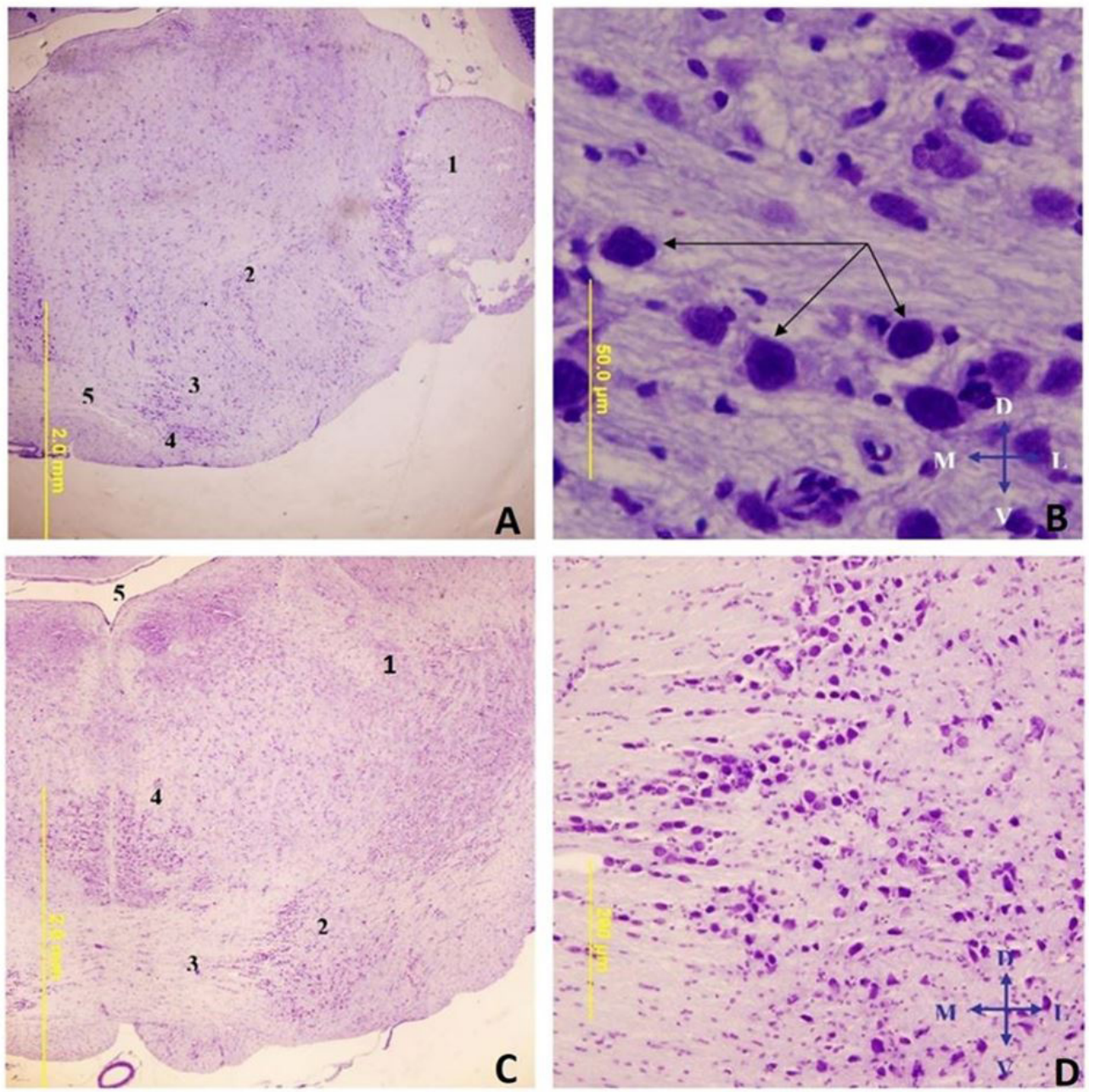

Figure 2. The MNTB of Phyllostomus hastatus bat. (A) A transverse section of the brainstem at the level of the middle cerebellar peduncle of the P. hastatus bat. 1. Middle cerebellar peduncle 2. Superior paraolivary nucleus 3. Medial nucleus of the trapezoid body 4. Ventral nucleus of the trapezoid body 5. Fibres of the trapezoid body; (B) Medium-sized, dark-staining, round/ oval cells (12.5 to $17.5 \mu \mathrm{m}$ diameter) in the caudal third of the MNTB of the P hastatus bat; (C) A transverse section at the rostral third of the MNTB of the P. hastatus bat. 1. Inferior colliculus 2. Medial nucleus of the trapezoid body 3. Fibres of the trapezoid body 4. Medial lemniscus 5. Fourth ventricle; (D) The fibres and cells of the rostral third of the MNTB of the P. hastatus bat (D-Dorsal, M-Medial, L-Lateral, V-Ventral). 
third (at the level of middle third of lateral lemniscus) and measured $560 \pm 54 \mu \mathrm{m}$ height and $505 \pm 40 \mu \mathrm{m}$ width.

Three types of cells viz., the dense staining multipolar cells, light staining multipolar cells and light staining round cells were observed in the MNTB of $P$. hastatus as in N. leporinus. (see Figure 2A). The dense staining multipolar cells (12.5 to $17.5 \mu \mathrm{m}$ diameter) were predominantly dispersed among the trapezoidal fibres. Very few large dense staining cells (17.5 to $25 \mu \mathrm{m}$ diameter) were also noticed at the level of caudal and middle third of the MNTB (see Figure 2B). At the rostral third, large dense-staining, multipolar cells were seen (17.5 to $25 \mu \mathrm{m}$ diameter) mostly in the ventral portion of the MNTB (see
Figure 2C). The trapezoid fibres were predominantly seen and dense and light staining, multipolar cells measuring (12.5 to $17.5 \mu \mathrm{m}$ diameter) were present between the fibres (see Figure 2D).

\subsection{Medial nucleus of trapezoid body of the Carollia perspicillata bat}

The mean body and brain weight of $C$. perspicillata bat weighed as $14.4 \pm 2.1 \mathrm{~g}$ and $3.74 \pm 0.75 \mathrm{~g}$ respectively. The MNTB was located as a distinct large cluster of cells, ventral and medial to the MSO (Figure 3A). It extends caudocranially from the level of facial nucleus to the level of pontine nuclei in the brain stem with a mean
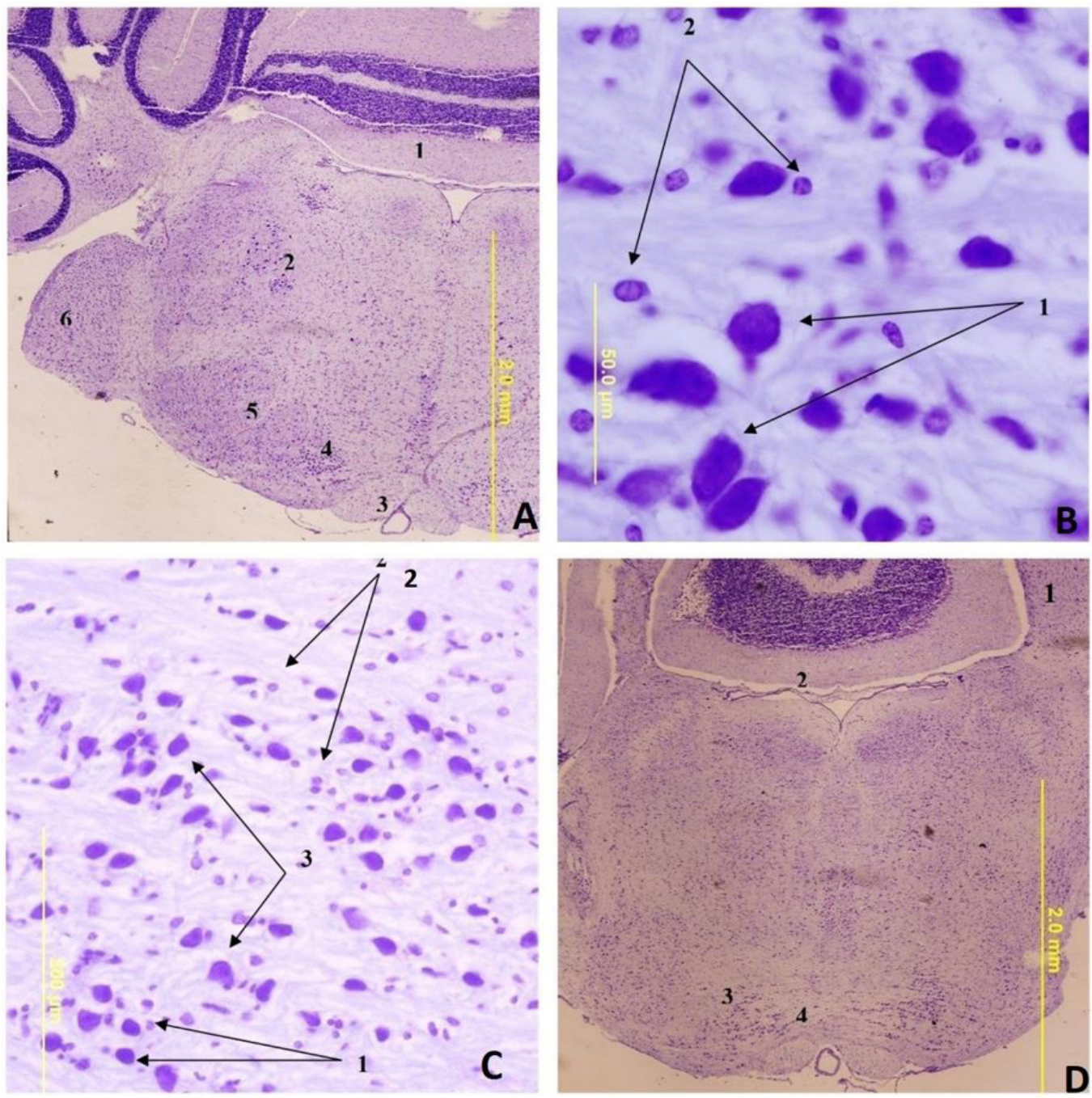

Figure 3. The MNTB of Carollia perspicillata bat. (A) A transverse section of the brainstem at the level of the facial nucleus of the Carollia perspicillata bat. 1. Cerebellum 2. Facial nucleus 3. Pyramid 4. Medial nucleus of the trapezoid body 5 . Superior olivary complex 6 . Cochlear nucleus; (B) The predominant cells of the caudal third of the MNTB of the C. perspicillata bat. 1. Large, oval cells (12.5 to $25.0 \mu \mathrm{m}$ in diameter) 2. Small round cells (5.0 $\mu \mathrm{m}$ diameter); (C) Three cell-types of the MNTB of the C. perspicillata bat. 1. Large, oval cells (12.5 to $25.0 \mu \mathrm{m}$ in diameter) 2. Small round cells (5.0 $\mu \mathrm{m}$ in diameter) 3. Large multipolar cells (20.0 to $32.5 \mu \mathrm{m}$ in diameter); (D) A transverse section of the brainstem at the level of the caudal inferior colliculus of the C. perspicillata bat. 1. Inferior colliculus 2. Cerebellum 3. Medial nucleus of the trapezoid body 4 . Fibres of the trapezoid body. 
length of $320 \pm 25 \mu \mathrm{m}$. It measured $370 \pm 39 \mu \mathrm{m}$ in height and $350 \pm 32 \mu \mathrm{m}$ in width at the caudal third (at the level of facial nucleus) and increased in size up to $390 \pm 46 \mu \mathrm{m}$ in height and $360 \pm 27 \mu \mathrm{m}$ in width at the middle third (at the level of caudal end of inferior colliculus) and reduced at the rostral third (at the middle of the inferior colliculus) to $360 \pm 28 \mu \mathrm{m}$ in height and $320 \pm 17 \mu \mathrm{m}$ in width.

Three types of cells viz., the dense staining large oval/ round/multipolar cells, light staining large multipolar cells and light staining small round cells were observed as in other bats. At the level of the facial nucleus, large round/ oval dense-staining cells (12.5 to $25.0 \mu \mathrm{m}$ diameter) were predominately seen. There were also a few small round cells of $5.0 \mu \mathrm{m}$ diameter dispersed among the large cells throughout the MNTB (Figure 3B). Laterally, more large dense staining multipolar cells (20.0 to $32.5 \mu \mathrm{m}$ diameter) were seen and ventrally, the small (5.0 $\mu \mathrm{m}$ average diameter) light staining round cells were mainly apparent. All three cell-types of cells were seen throughout the MNTB and the fibres of the TB traversed the entire MNTB (Figure 3C) at the middle third of the MNTB at the level of the most caudal end of the inferior colliculus. The medial part of the MNTB was more densely-populated than the lateral part with all three cell types (Figure 3D).

\section{Discussion}

The general outline of the MNTB within the superior olivary complex (SOC) in all the bats studied in the present study is similar to the other mammals. The MNTB appeared large in size, extending medially to the raphe and penetrated by most of the fibres of passage in all the bats studied. The auditory nuclei are relatively larger in echolocating animals like the marmoset (Prado Reis and Abrantes Erhart, 1979), dolphins (Thomas et al., 2004; DeLong et al., 2007) and bats (Zook and Casseday, 1982; Gibbons et al., 2013a, b, 2019; Adogwa et al., 2014; Gibbons et al., 2019) than the human and non-human primates (Neuweiler and Covey, 2000) which is similar in the present study. The very well developed MNTB in $N$. leporinus $(1160 \pm 124 \mu \mathrm{m}$ in length) indicated that this bat heavily depends on the echolocation than the two other bats studied.

The insectivorous bats rely heavily on echolocation for the pursuit and capture of prey would have larger auditory nuclei than do phytophagous species (Hutcheon et al., 2002). The Phyllostomus species which also echolocate while foraging but the size of the MNTB is smaller when compare with the $N$. leporinus in the present study. The body and brain weight do not reflect proportionately on the size of the MNTB in the present study as the body and brain weight of the $P$. hastatus measured as $73.24 \pm 7.25 \mathrm{~g}$ and $8.57 \pm 0.67 \mathrm{~g}$ respectively which is higher than the $N$. leporinus $48.1 \pm 3.5 \mathrm{~g}$ and $6.93 \pm 0.47 \mathrm{~g}$, whereas the length of the MNTB measured $400 \pm 59 \mu \mathrm{m}$ in P. hastatus and $1160 \pm 124 \mu \mathrm{m}$ in N. leporinus. The differences in length of the entire MNTB of the three bats used were attributed to the varied feeding strategies, where it is surmised that the N. leporinus bat, with the largest MNTB, requires echolocation to a higher degree than the other two bats studied (Neuweiler, 1989; Aguirre et al., 2000; Dumont, 2007).

The $N$. leporinus emit echolocation signals that are either at constant frequency $(\mathrm{CF})$, frequency-modulated (FM) or a combination of the two (CF-FM). CF-FM signals have CF followed by a FM. In an CF-FM signal, the CF are typically $8.9 \mathrm{~ms}$ with a frequency of 52.8 $56.2 \mathrm{kHz}$ while the FM ranges up to $3.9 \mathrm{~ms}$ with $25.9 \mathrm{kHz}$ bandwidth. The best sensitivity is at the range of $32-57 \mathrm{KHz}$ (Schnitzler et al., 1994). The hearing range of $P$. hastatus was 1.8 to $105 \mathrm{kHz}$ with best sensitivity is at $20 \mathrm{kHz}$ (Koay et al., 2002) whereas the $C$. perspicillata hearing ranged from 5.2 to $150 \mathrm{kHz}$ and best at $15 \mathrm{kHz}$ (Koay et al., 2003). The best sensitivity of the hearing range is high in $N$. leporinus which is having a well-developed MNTB than other bats in the present study. The maximum range of hearing is seen in C. Perspicillata followed by P. hastatus, however there was no hypertrophy of the MNTB observed in the present study. The present findings do not support the theory that size of MNTB covaries with the frequency spectrum across which a species can hear, especially as high frequency (and ultrasound hearing) is added by species, more MNTB neurons are needed to cover the increased tonotopic axis well.

The MNTB and VNTB were not clearly demarcated in the present study as in other bats (Grothe and Park, 2000) whereas the VNTB is well-defined in the cats (Schwartz, 1992). The VNTB appeared as cluster of cells on the ventral aspect of the MNTB in P. hastatus bats whereas the VNTB was not apparent in $N$. leporinus and $C$. perspicillata bats. It may be due to the looser arrangement of VNTB cells than in the P. hastatus bat. The VNTB is one of the major sources of glycinergic inhibitory input to the ipsilateral MNTB and able to suppress MNTB spiking when activated (Awatramani et al., 2005) which will make the bats more sensitive to the interaural level disparities. The $P$. hastatus is omnivorous, and, although it eats fruit and insects, it prefers meat, preying on small vertebrates, including other bats. Like many other bats that forage for fruit amidst leaf clutter or detect live prey against a solid surface (gleaners), it uses relatively low-intensity, brief sonar pulses when foraging (Kalko and Schnitzler, 1993; Kalko and Condon, 1998; Neuweiler, 1989). It may also listen passively for sounds generated by the movements of its prey, a behavior thought to be common in bats that take large prey from substrates (Belwood, 1986). The presence of VNTB could possibly associated with passive listening and good low-frequency sensitivity.

The cell types of the MNTB of the bats in the present study were similar to those found in other bats. The principal cells of the MNTB in all the bats studied are large, densestaining cells (12.5 to $25.0 \mu \mathrm{m}$ diameter) with variable shapes; round, elongated or multipolar. The other large cells with light-stained nuclei of same dimensions observed in the present study would be the same type of dark stained cells. The variation in the stainability due to the abundance 
of Nissl bodies and it indicated that the dark stained cells are metabolically active. Small light staining round cells observed in the present study also similar to the findings in other bats (Schwartz, 1992).

The principal cells of the MNTB receive excitatory input from GBCs of the contralateral AVCN by the prominent Calyces of Held. These principal cells then project to the ipsilateral LSO (LSO) to inhibit postsynaptic neurons and provide a basis for interaural level detection (ILD), required for sound localization.

\section{Conclusion}

The present study revealed that although the MNTB is large in all the bats generally, there appears to be differences among the species. The MNTB in all bats comprised three main cell types: dense-staining, lightstaining multipolar cells and round cells. The VNTB is clearly demarcated in P. hastatus bat. The large size of the MNTB of the N. leporinus bat compared to the other two species are probably due to the fact that it relies heavily on echolocation in order to feed. The $P$. hastatus and the C. perspicillata use echolocation as well but also rely on hearing, vision and smell.

\section{Acknowledgements}

The authors thank the staff and technicians from the School of Veterinary Medicine especially Mr. Roger John and Mr. Lester Gilkes for all of their support with the laboratory work and data collection required for this research. The authors also thank the University of the West Indies, St. Augustine, Trinidad and Tobago for the financial and infrastructure support for this project.

\section{References}

ADOGWA, A., SUNDARAM, V., GIBBONS, I. and ODEKUNLE, A., 2014. Cytoarchitecture of the medial geniculate body of three species of bats: Noctilio leporinus, Phyllostomus hastatus and Carollia perspicillata. Annual Research \& Review in Biology, vol. 4, no. 3, pp. 1-9. http://dx.doi.org/10.9734/ARRB/2014/4961.

AGUIRRE, L.F., HERREL, A., VAN DAMME, R. and MATTHYSEN, E., 2000. Ecomorphological analysis of trophic niche partitioning in a tropical savannah bat community. Proceedings of Royal Society of London (Biological Sciences), vol. 269, no. 1497, pp. 124-132. https://doi.org/10.1098/rspb.2002.2011.

ASHIDA, G. and CARR, C.E., 2011. Sound localization: jeffress and beyond. Current Opinion in Neurobiology, vol. 21, no. 5, pp. 745-751. http://dx.doi.org/10.1016/j.conb.2011.05.008. PMid:21646012.

AWATRAMANI, G.B., TURECEK, R. and TRUSSELL, L., 2005. Staggered development of GABAergic and glycinergic transmission in the MNTB. Journal of Neurophysiology, vol. 93, no. 2, pp. 819-828. http://dx.doi.org/10.1152/jn.00798.2004. PMid:15456797.

BELWOOD, J.J., 1986. Foraging behavior, prey selection, and echolocation in phyllostomine bats (Phyllostomidae). In: P.E.
NACHTIGALL and P.W.B. MOORE, eds. Animal sonar processes and performance. New York: Plenum Press.

BORST, J.G.G. and SORIA VAN HOEVE, J., 2012. The Calyx of Held Synapse: From Model Synapse to Auditory Relay. Annual Review of Physiology, vol. 74, no. 1, pp. 199-224. http://dx.doi. org/10.1146/annurev-physiol-020911-153236. PMid:22035348.

CASEY, M.A. and FELDMAN, M.L., 1985. Aging in the rat medial nucleus of the trapezoid body. II. Electron microscopy. The Journal of Comparative Neurology, vol. 232, no. 3, pp. 401413. http://dx.doi.org/10.1002/cne.902320311. PMid:3973099.

DELONG, C.M., AU, W.W.L. and STAMPER, S.A., 2007. Echo features used by human listers to discriminate among objects that vary in material or wall thickness: implications for echolocating dolphins. The Journal of the Acoustical Society of America, vol. 121, no. 1, pp. 605-617. http://dx.doi.org/10.1121/1.2400848. PMid:17297814.

DUMONT, E.R., 2007. Feeding mechanisms in bats: variation within the constraints of flight. Integrative and Comparative Biology, vol. 47, no. 1, pp. 137-146. http://dx.doi.org/10.1093/ icb/icm007. PMid:21672826.

ELVERLAND, H.H., 1978. Ascending and intrinsic projections of the superior olivary complex in the cat. Experimental Brain Research, vol. 32, no. 1, pp. 117-134. http://dx.doi.org/10.1007/ BF00237396. PMid:658183.

FENZL, T. and SCHULLER, G., 2005. Echolocation calls and communication calls are controlled differentially in the brainstem of the bat Phyllostomus discolor. BMC Biology, vol. 3, pp. 3-17. PMid:16053533.

GIBBONS, I., ADOGWA, A., VENKATESAN, S., ISITOR, G.N. and ODEKUNLE, A., 2013a. The cytoarchitecture of the cochlear nuclear complex of two species of bats: carollia perspicilliata and Phyllostomaus hastatus. European International Journal Science of Technology, vol. 2, no. 8, pp. 226-234.

GIBBONS, I., SUNDARAM, V., ADOGWA, A. and ODEKUNLE, A., 2013b. The Cytoarchitecture of the Inferior Colliculus of Two Species of Bats: Noctilio leporinus (Fish Eating) and Phyllostomus Hastatus (Carnivorous/ Omnivorous). International Journal of Life Science and Medical Research, vol. 3, no. 4, pp. 173-178. http://dx.doi.org/10.5963/LSMR0304005.

GIBBONS, I., SUNDARAM, V., ADOGWA, A. and ODEKUNLE, A., 2019. Cytoarchitecture of the superior olivary complex of three neotropical species of bats (Noctilio leporinus, Phyllostomus hastatus and Carollia perspicillata) with different foraging behavior. Brazilian Journal of Biology = Revista Brasileira de Biologia

GROTHE, B. and PARK, T.J., 2000. Structure and function of the bat superior olivary Complex. Microscopy Research and Technique, vol. 51, no. 4, pp. 382-402. http://dx.doi.org/10.1002/10970029(20001115)51:4<382::AID-JEMT7>3.0.CO;2-7. PMid:11071721.

GROTHE, B., PECKA, M. and MCALPINE, D., 2010. Mechanisms of sound localization in mammals. Physiological Reviews, vol. 90, no. 3, pp. 983-1012. http://dx.doi.org/10.1152/physrev.00026.2009. PMid:20664077.

HARRISON, J.M. and WARR, W.B., 1962. A study of the cochlear nuclei and ascending auditory pathways of the medulla. The Journal of Comparative Neurology, vol. 119, no. 3, pp. 341379. http://dx.doi.org/10.1002/cne.901190306. PMid:13952992.

HELD, H., 1893. Die centrale gehörleitung. Archiv für Anatomie, Physiologie und Wissenschaftliche Medicin, vol. 17, pp. 201-248. 
HUTCHEON, J.M., KIRSCH, J.A.W. and GARLAND JUNIOR, T.A., 2002. Comparative analysis of brain size in relation to foraging ecology and phylogeny in the Chiroptera. Brain, Behavior and Evolution, vol. 60, no. 3, pp. 165-180. http://dx.doi. org/10.1159/000065938. PMid:12417821.

KALKO, E.K.V. and CONDON, M.A., 1998. Echolocation, Olfaction and Fruit Display: How Bats Find Fruit of Flagellichorous Cucurbits. Functional Ecology, vol. 12, no. 3, pp. 364-372. http:// dx.doi.org/10.1046/j.1365-2435.1998.00198.x.

KALKO, E.K.V. and SCHNITZLER, H.U., 1993. Plasticity in echolocating signals of European pipistrelle bats in search flight: implications for habitat use and prey detection. Behavioral Ecology and Sociobiology, vol. 33, no. 6, pp. 415-428. http:// dx.doi.org/10.1007/BF00170257.

KOAY, G., BITTER, K.S., HEFFNER, H.E. and HEFFNER, R.S., 2002. Hearing in American leaf-nosed bats. I: phyllostomus hastatus. Hearing Research, vol. 171, no. 1-2, pp. 96-102. http:// dx.doi.org/10.1016/S0378-5955(02)00458-6. PMid:12204353.

KOAY, G., HEFFNER, R.S., BITTER, K.S. and HEFFNER, H.E., 2003. Hearing in American leaf-nosed bats. II: carollia perspicillata. Hearing Research, vol. 178, no. 1-2, pp. 27-34. http:// dx.doi.org/10.1016/S0378-5955(03)00025-X. PMid:12684174.

MOREST, D.K., 1968. The collateral system of the medial nucleus of the trapezoid body of the cat, its neuronal architecture and relation to the olivo-cochlear bundle. Brain Research, vol. 9, no. 2, pp. 288-311. http://dx.doi.org/10.1016/0006-8993(68)90235-7. PMid:5679830.

NEUWEILER, G. and COVEY, E., 2000. The biology of bats. New York: Oxford University Press.

NEUWEILER, G., 1989. Foraging ecology and audition in echolocating bats. Trends in Ecology \& Evolution, vol. 4, no. 6, pp. 160-166. http://dx.doi.org/10.1016/0169-5347(89)90120-1. PMid:21227342.
PRADO REIS, F. and ABRANTES ERHART, E., 1979. The brain of the marmoset (Callithrix jacchus). Acta Anatomica, vol. 103, no. 3, pp. 350-357. http://dx.doi.org/10.1159/000145034. PMid:107717.

SCHNITZLER, H.U., KALKO, E.K.V., KAIPF, I. and GRINNELL, A.D., 1994. Fishing and echolocation behavior of the greater bulldog bat, Noctilio leporinus, in the field. Behavioral Ecology and Sociobiology, vol. 35, no. 5, pp. 327-345. http://dx.doi. org/10.1007/BF00184422.

SCHWARTZ, I.R., 1992. The superior olivary complex and lateral lemniscal nuclei. In: D.B. WEBSTER, A.N. POPPER and R.R. FAY, eds. The mammalian auditory pathway: neuroanatomy. New York: Springer. Springer Handbook of Auditory Research, vol. 1. http://dx.doi.org/10.1007/978-1-4612-4416-5_4.

SMITH, P.H., JORIS, P.X., CARNEY, L.H. and YIN, T.C., 1991. Projections of physiologically characterized globular bushy cell axons from the cochlear nucleus of the cat. The Journal of Comparative Neurology, vol. 304, no. 3, pp. 387-407. http:// dx.doi.org/10.1002/cne.903040305. PMid:2022755.

SMITH, P.H., JORIS, P.X. and YIN, T.C., 1998. Anatomy and physiology of principal cells of the medial nucleus of the trapezoid body (MNTB) of the cat. Journal of Neurophysiology, vol. 79, no. 6, pp. 3127-3142. http://dx.doi.org/10.1152/jn.1998.79.6.3127. PMid:9636113.

SPANGLER, K.M., WARR, W.B. and HENKEL, C.K., 1985. The projections of principal cells of the medial nucleus of the trapezoid body in the cat. The Journal of Comparative Neurology, vol. 238, no. 3, pp. 249-262. http://dx.doi.org/10.1002/cne.902380302. PMid:4044914.

THOMAS, J.A., MOSS, C.F. and VATER, M., 2004. Echolocation in bats and dolphins. New York: The University of Chicago Press.

ZOOK, J.M. and CASSEDAY, J.H., 1982. Origin of ascending projections to inferior colliculus in the mustache bat, Pteronotus parnellii. The Journal of Comparative Neurology, vol. 207, no. 1, pp. 14-28. http://dx.doi.org/10.1002/cne.902070103. PMid:7096636. 